\title{
Determinants of MNE Activity in Poland: The Case of Firms from EU-15
}

\author{
Andrzej Cieślik
}

\begin{abstract}
A B S T R A C T
Objective: The main purpose of this paper is to validate empirically the theoretical predictions of the modified knowledge capital model of multinational enterprise and identify the main reasons for undertaking international production in Poland by foreign firms from the EU-15 countries.
\end{abstract}

Research Design \& Methods: Our theoretical framework refers to the physical capital augmented knowledge capital model that combines both horizontal and vertical reasons for foreign direct investment. The empirical implementation of the theoretical framework is based on the negative binomial model and the bilateral dataset covering 15 old EU member states over the period 1989-2014 which yields a total of 390 observations.

Findings: Our estimation results indicate that the extent of multinational activity in Poland is positively related to both differences in relative factor endowments and similarity in the relative country size which confirms the importance of both reasons for undertaking foreign direct investment in Poland.

Implications \& Recommendations: The empirical evidence confirms the predictions of the modified knowledge capital model and points to the horizontal as well as vertical motives for undertaking foreign direct investment in Poland. These findings suggest that government should not try to attract only one type of FDI.

Contribution \& Value Added: The originality of this work lies in the empirical implementation of the theoretical framework that allows distinguishing between horizontal and vertical reasons for foreign direct investment.

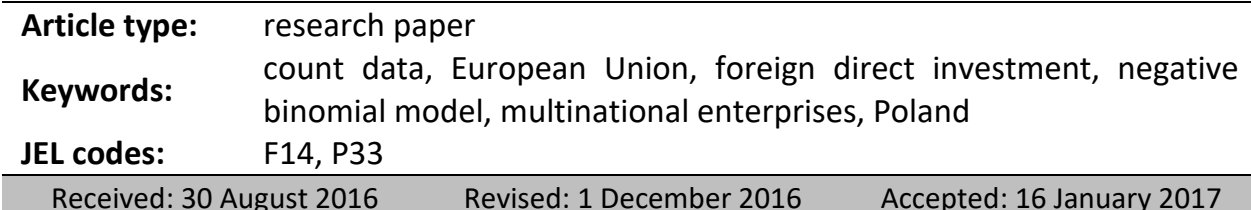

Suggested citation:

Cieślik, A. (2017). Determinants of MNE Activity in Poland: The Case of Firms from EU-15. Entrepreneurial Business and Economics Review, 5(1), 151-167, DOI: http://dx.doi.org/10.15678/EBER.2017.050109 


\section{INTRODUCTION}

In the recent years, considerable attention has been devoted to studying the factors that determine the inflows of foreign direct investment (FDI) to various countries and regions of the world. The vast literature documenting the emergence of multinational enterprises (MNEs) shows a variety of different approaches. The theories of international production that have been proposed to explain the determinants of multinational activity can be broadly categorized into three main stands, namely: the neoclassical literature, the international business literature and the new trade theory (NTT) literature. However, one of the fundamental questions that they all aim at answering concerns the motivation of firms behind the choice of affiliate production rather than exporting or licensing arrangements as the way of servicing a foreign market.

For many years research on the determinants of the extent of MNE activity was purely theoretical. Empirical studies that attempted to validate the predictions of the competing theories of multinational enterprise were relatively scarce. Especially, the empirical tests of the MNE theories that belong to the NTT strand in the literature have not started until the early 1990s. Initially they were focused almost entirely on American multinationals, while MNEs from other countries until recently received much less attention. In particular, the empirical evidence on multinational activity in the new member countries of the European Union (EU) still remains relatively scarce.

This paper aims at filling a part of the existing gap in this empirical literature by focusing on the determinants of the multinational activity in Poland - the biggest of the new EU member states which attracted most FDI in the region. With over 174 billion euros in FDI at the end of 2014 Poland has emerged as one of the most attractive host countries for the location of MNE activities among the new EU member states in the last several years (National Bank of Poland, 2015). However, the distribution of FDI in Poland according to the country of origin is skewed towards several main source countries. The vast majority of FDI in Poland originates from the old EU-15 countries that differ in terms of their size as well as in relative factor endowments. The three main source countries in 2014 were: the Netherlands (29.9 bln), Germany (28.1 bln) and Luxembourg (19.9 bln), respectively which accounted for almost $45 \%$ of inward FDI stock in Poland.

The main purpose of this paper is to validate empirically the theoretical predictions of the modified knowledge capital (KC) model of the multinational enterprise, that belongs to the NTT strand in the MNE literature, and identify the main reasons for undertaking FDI in Poland by multinational firms originating from the old EU-15 countries. Extensive citations and significant previous empirical research for other countries suggest that the KC model is regarded in the mainstream economics as the most general theory of the multinational enterprise that is currently available as it combines both horizontal and vertical reasons for undertaking FDI (Markusen, 2013). The empirical implementation of this theoretical framework for Poland is based on the bilateral dataset on multinational firms from the EU-15 countries and covers the period 1989-2014 which yields a total of 390 observations. The negative binomial model is used as the preferred estimation technique compared to the simple Poisson model due to overdispersion present in the dataset. The paper contributes to a better understanding of determinants of multinational activity in Poland and its contribution of this paper to the 
MNE literature is mainly empirical. In particular, in contrast to previous empirical studies that were based on the original KC model, in addition to differences in GDP per capita, the statistical data on differences in both physical and human capital per worker that come from the most recent edition of PennWorld Table 9.0 are employed as the actual measures of differences in relative factor endowments.

The remainder of this paper is organized as follows. In the next section we survey the relevant literature on the theory of multinational enterprise that derives from the NTT. Then, we describe the analytical framework, discuss the research hypotheses, present definitions and sources of our explanatory variables and describe the empirical methodology. Finally, we discuss our estimation results. Concluding remarks, policy guidelines and directions for future research are provided in the last section.

\section{LITERATURE REVIEW}

Early theoretical studies based on the neoclassical assumptions viewed FDI as a part of the portfolio theory of international capital flows. According to this view these flows were driven by international differences in return on capital. The early theoretical studies on FDI, such as MacDougall (1960) or Kemp (1962), viewed the expansion of multinational firms as the transfer of financial or physical capital. According to these studies capital should flow from capital-abundant to capital-scarce countries and between countries with the same factor endowments capital flows should not be observed. However, the predictions of these studies were not in line with reality as the largest share of multinational activity occurs between developed countries that are similar both in terms of their relative factor endowments and economic size. The traditional neoclassical approach was also criticized because of relying on the set of very unrealistic assumptions, such as constant returns to scale (CRS) and perfect competition, which were not in line with the key industry-level stylized facts on FDI. ${ }^{1}$

The shortcomings of the formal neoclassical approach led to the rejection of the neoclassical strand in the MNE literature by international business economists and the development of an alternative eclectic strand in the literature. The major early representative of this strand is Dunning's (1977) OLI conceptual framework that later became the convenient point of departure for more formal theoretical modeling. ${ }^{2}$ However, the developments in the NTT provided a set of models that proved very useful in studying the emergence of multinational enterprises and foreign direct investment in a formal way. In this strand in the MNE literature two main reasons why a firm should go multinational were identified: efficiency-seeking and market-seeking. According to the first, firms internationalize produc-

\footnotetext{
${ }^{1}$ For example, Markusen (2002, p. 6) noted that: i) "large differences exist across industries in the degree to which production and sales are accounted for by multinational firms", ii) "multinationals tend to be important in industries that a) have high levels of R\&D relative to sales, b) employ large number of professional and technical workers as a percentage of their total workforces, c) produce new and/or technologically complex products, and d) have high levels of product differentiation and advertising", iii) "multinationals tend to be firms in which the value of the firms' intangible assets is large relative to its market value". Moreover, another problem was that in the neoclassical perfectly competitive constant returns approach firms were infinitely small and it was not possible to study directly the investment decisions that took place within the firm.

${ }^{2}$ In the subsequent years a variety of alternative informal conceptual frameworks were proposed by international business economists. However, as this paper relates to the NTT strand in the MNE literature hence summarizing the international business strand in the MNE literature goes beyond the scope of this paper.
} 
tion and become MNEs in order to get access to inputs at lower costs. FDI undertaken with the aim of reducing production costs is referred to as vertical FDI as it involves fragmenting the value chain internationally and locating various stages of production in countries where factors used intensively in particular stages are relatively cheap. According to the second approach, MNEs are vehicles to overcome distance and lower costs of foreign markets access. FDI undertaken to serve local markets is often horizontal FDI and refers to producing abroad similar goods and services as in the home country.

Horizontal FDI constitutes so far the largest fraction of MNE activity in the contemporary world economy. It occurs mostly between developed countries that are similar in terms of their relative factor endowments as well as their economic size. To explain this phenomenon a number of NTT models of horizontally integrated MNE have been developed. The central plank of these models is called the proximity-concentration tradeoff according to which FDI occurs when the benefits of producing in the foreign market outweigh the loss of economies of scale from producing exclusively in the firm's home plant [Neary, 2009]. The early examples of this approach are the models developed by Krugman (1983) and Markusen (1984). Initially, their models were extremely simple assuming identical factor endowments across countries and were based on partial equilibrium frameworks. These models were subsequently extended and modified by a number of authors including, inter alia, Horstmann and Markusen (1987), Smith (1987), Motta (1992), Brainard (1993a), Markusen and Venables (1998, 2000), Helpman et al. (2004), Sinha (2010), Collie (2011), and more recently Cieślik (2013; 2015a,b; 2016). In their models firms had different channels of entering a foreign market and each of them incurred different costs. Although particular models differed with respect to assumptions concerning the market structure, the main prediction was as follows: firms were more likely to enter the foreign market via FDI rather than via exporting the higher the trade costs and the lower fixed costs of entry and the size of economies of scale at the plant level compared to the firm level.

With the falling transportation and communication costs between developed and developing countries an increasing part of multinational activity is explained by the efficiencyseeking motive. The first models of a vertically-integrated multinational enterprise were developed by Helpman $(1984,1985)$ and Helpman and Krugman (1985). These models can be regarded as extended versions of the Chamberlin-Heckscher-Ohlin NTT models in which differences in relative factor endowments between trading partners were so large that trade alone was not sufficient for achieving factor price equalization. For example, if one country had a much higher endowment of capital per worker than the other then it would be profitable for the firm to split up the value chain by locating capital intensive parts of the production process in the capital abundant country and moving labor intensive segments to low cost destinations. According to this approach parent firms from the capital abundant country exported capital intensive products, such as headquarter services and intermediate inputs, to its subsidiaries located in the labour abundant country while subsidiaries exported a substantial fraction of their output back to the home country.

Throughout the 1980s and 1990s horizontal and vertical models of multinational enterprise were treated as two separate strands in the literature. The next step in the development of the theory of multinational enterprise aimed at combining the horizontal and vertical approaches into a hybrid framework in which firms can choose between national, horizontal and vertical strategies. This has been done by Markusen 
(2002) who called this integrated framework the knowledge capital model. The KC model allows national firms, horizontal multinationals and vertical multinationals to emerge endogenously in the equilibrium, depending on various combinations of home and host country characteristics. In the later years the knowledge capital model has been extended by various authors in many directions. These extensions include, inter alia, the theoretical studies by Bergstrand and Egger (2007, 2013), Markusen and Strand (2009), Markusen and Stähler (2011), Chen et al. (2012), and most of them are summarized in Markusen (2013). In particular, one of the most important recent extensions of this framework is the incorporation of physical capital in addition to the human capital that allows the direct comparison of the knowledge capital model with the horizontal and vertical models of the multinational enterprise in which differences in relative factor endowments were determined by the capital to labour ratios.

Empirical studies that attempted to validate the predictions of the new theories of multinational enterprise have not started until the early 1990s. Initially they were focused almost entirely on American multinationals while firms from other counties received much less attention. These studies were initiated by Brainard (1993b, 1997) who tested two alternative hypotheses: the proximity-concentration tradeoff for horizontally integrated MNEs and relative factor endowments for vertically integrated MNEs. She found that the majority of American MNEs were integrated horizontally, and not vertically. However, Carr, Markusen and Maskus (2001) estimated specifications directly derived from the knowledge capital model and found that American MNEs were integrated not only horizontally, but also vertically. Subsequent studies by Braconier et al. (2006) and Davies (2008) found more evidence in favour of vertical production.

Since then the determinants of foreign direct investment flows have been widely investigated also in other countries. In particular, the opening of the economies of Central and East European countries (CEECs) to FDI in the early 1990s stimulated interest in studying determinants of FDI into those countries. Initially, empirical studies for those countries were conducted treating all the countries in the whole region jointly. Examples of such studies include Lansbury et al. (1996), Brenton et al. (1999), Benacek et al. (2000), Resmini (2000), Garibaldi et al. (2001), Bevan and Estrin (2004), Carstensen and Toubal (2004), Cieślik and Ryan (2004), Baniak et al. (2005), Gorbunova et al. (2012), and most recently also Wach and Wojciechowski (2016). Subsequently, studies for individual CEECs started to appear. In particular, determinants of inward FDI in Poland were studied by Cieślik (1996, 2006), Witkowska (1996), Przybylska (1998, 2001), Liberska (1999), Polak (2002), Markowicz and Miłaszewicz (2007), Ancyparowicz (2009), Lizińska (2012), and more recently Jasiniak (2014) and Owczarczuk (2014). ${ }^{3}$

The above literature review clearly shows that substantial research was done on the determinants of foreign direct investment location decisions of multinational corporations in Central and Eastern Europe. In particular, considerable attention has been paid especially to the factors influencing the volume of inward FDI in transition economies that

\footnotetext{
${ }^{3}$ In many cases previous studies presented simple analogies based on the research results for other countries or were limited to case studies and survey evidence for a relatively small number of firms which did not allow making generalizations based on a large number of cases. In addition, only in a very limited number of studies more formal econometric evidence on FDI determinants was presented. However, the majority of these econometric studies were based on ad hoc regressions without firm references to the theory which made the interpretation of estimation results difficult.
} 
recently became member countries of the European Union. In each of the papers the focus of analysis was on the country specific determinants of foreign direct investment location decisions. What seems to be even more important, all the described studies aimed at comparing the sets of explanatory variables identified as significant for the amount of FDI flows received by various countries due to a willingness to explain the differences in foreign capital distribution among the CEECs. However, with the exceptions of the early studies by Cieślik $(1996,2006)$ who approximated differences in relative factor endowments with GDP per capita differences, none of the aforementioned studies tried to test empirically the predictions derived directly from the formal models of the multinational enterprise that belong to the NTT strand in the MNE literature and distinguish between horizontal and vertical FDI. Therefore, in contrast to the previous empirical studies, in addition to studying the differences in GDP per capita in the current research we will also study the role of differences in relative human and physical capital endowments.

\section{MATERIAL AND METHODS}

In order achieve our research goal and identify the main reasons for undertaking FDI in Poland by foreign firms from the EU-15 countries in this study we derive a number of research hypotheses on the basis of the modified KC model. This model is based on the general equilibrium approach that incorporates both horizontal and vertical reasons for FDI. There are three main assumptions that allow different types of firms to arise endogenously in equilibrium (Markusen, 2013). First, the KC model assumes that, like in the pure vertical model, creation and services of knowledge-based assets, such as $R \& D$, could be geographically separated from production and supplied to foreign subsidiaries by the headquarter at a fairly low cost. Second, it assumes that headquarter services are more human-capital intensive than production units. Third, it assumes that these knowledge-based services have a joint-input characteristic. In other words, they could be simultaneously used by multiple production facilities, giving rise to firmlevel scale economies, like in the pure horizontal model. The first two assumptions provide incentives for the international fragmentation of production and locating various segments of production process where the factors used intensively in each segment are relatively cheap. The third assumption motivates horizontal investment that replicates the production of the same goods or services in different countries.

Unfortunately, the KC model cannot be solved analytically. The analytical difficulties imply that most results have to be derived from numerical simulations. These simulations generate predictions on the relationship between the extent of multinational activity and country characteristics. For example, national firms exporting to each other's market would be the dominant type when countries are similar in economic size and relative factor endowments and trade costs between them are low. Horizontal multinationals would dominate when countries are similar in economic size and relative factor endowments and trade costs are high. However, if countries are dissimilar in either size or in relative factor endowments one country will be favoured as a location of both headquarters and production activities or one of these two activities.

In particular, if countries are dissimilar in size but similar in relative factor endowments then national firms located in the large country would be favoured as they could avoid installing costly capacity in the smaller market. On the other hand, if countries are similar in 
size but dissimilar in relative factor endowments vertical multinationals would be the dominant type as there is an incentive to split the production process and concentrate headquarters in the human-capital abundant country and production in the labor-abundant country, unless trade costs are high. The extent of multinational activity in the KC model is the largest when the parent country is moderately small and highly abundant in human capital.

Even though most findings of the $\mathrm{KC}$ model derived from numerical simulations, the model generates a number of testable predictions, relating the extent of multinational activity to country characteristics. The predictions of the $\mathrm{KC}$ model can be tested using statistical data on FDI from old EU-15 countries to Poland. However, it should be noted that Markusen (2002) and his followers in their theoretical frameworks analyzed bilateral multinational activity, while in our study, we take into account only unilateral multinational activity, i.e. our dataset includes one-way FDI only, i.e. FDI from EU-15 countries to Poland. Therefore, our research hypotheses on FDI from EU-15 to Poland derived on the basis of the modified KC model can be formulated as follows:

H1: Total income and the similarity in market size between EU-15 countries and Poland are associated positively with multinational activity as they motivate horizontal FDI.

H2: The differences in relative factor endowments between EU-15 countries and Poland are associated positively with multinational activity as they motivate vertical FDI.

H3: Higher trade costs between EU-15 countries and Poland discourage vertical FDI and encourage horizontal FDI so the overall effect is unclear and must be determined empirically.

The KC model predicts how multinational activity on a bilateral basis can be related to combined market sizes, differences in economic country size, relative factor endowments and trade costs. In order to validate empirically the theoretical predictions of the KC model we use a panel of cross-country observations for Poland over the period 19892014. Country characteristics determining the extent of multinational activity between countries in the KC model appear also in pure horizontal and vertical models although their expected impacts differ across models. Therefore, checking whether the market access motive or the production cost motive better explains the cross-country pattern of FDI in Poland can be done by evaluating the signs and significance of the estimated coefficients on various country-pair characteristics obtained from the single empirical setting.

The two key variables that allow distinguishing between competing reasons for FDI are the measures of similarity in relative factor endowments and economic size between the home and the host countries. In particular, the horizontal reason predicts that the involvement of multinational firms in the host country would decrease with increasing differences in relative factor endowments while the vertical reasons predicts an opposite relationship. Therefore, if the estimated coefficient on the measure of differences in relative factor endowments between the home and the host countries turns negative, then the market access motive should be more important, while if it turns positive, then the production cost motive should be more important. ${ }^{4}$

\footnotetext{
${ }^{4}$ In the KC model, there is some non-monotonicity in the relationship between the measure of involvement of MNEs in the host country and differences in relative factor endowments. The rise in human capital per worker in the human capital-scarce country, that reduces differences in relative factor endowments between countries, leads to a fall in the foreign involvement in the host country for a relatively similar countries but increases
} 
Despite ongoing convergence between Poland and the EU-15 the differences in relative factor endowments between these countries are still substantial, hence we should expect a positive sign of the coefficient on differences in relative factor endowments if the production cost motive were to dominate. In this study we use two ways of measuring differences in the relative factor endowments between countries. First, we to assure comparability with the previous studies we proxy for differences in relative factor endowments between Poland and its investment partners with the per capita difference in GDP (GDPPCDIFF) calculated using output-side real GDP at chained PPPs and expressed in constant 2011 US dollars.

Then, in order to calculate cross-country differences in relative factor endowments we also use the actual factor data on human as well as physical capital. The differences in human capital endowments (HLDIFF) are calculated using the human capital index, based on years of schooling and returns to education. The differences in physical capital endowments (KLDIFF) are calculated using the capital stock expressed in PPPs in constant 2011 US dollars and the number of people employed. The data necessary to calculate differences in relative factor endowments come from the PennWorld Table (PWT) 9.0 available on www.ggdc.net/pwt.

The second key explanatory variable is similarity in economic size between the home and the host countries. Both the pure horizontal and the hybrid knowledge capital model predict a negative relationship between differences in the country size and the extent of involvement of multinational firms in the host country, while in the pure vertical model similarity in country size does not play any role. Therefore, we can expect a positive sign of the estimated coefficient on this variable if the market access motive is important and no relationship for the production cost motive. To measure similarity in relative country size we use the size dispersion index proposed by Helpman (1987). The value of this index is positively related to similarity in size of investment partners and is maximized when both the home and the host countries are of equal size. In order to calculate the size similarity index (SIMILARITY) data on output-side real GDP at chained PPPs and expressed in constant 2011 US dollars for Poland and particular EU-15 countries is used. This data also comes from the PennWorld Table (PWT) 9.0.

In addition to the measures of differences in relative factor endowments and similarity in economic size that are used for model identification we also include a number of additional variables in our estimating equation in order to control for other effects. To control for the absolute economic size of investment partners we include the sum of Poland's and the home country's GDP (GDPSUM). In the theoretical models that were surveyed in the previous section the absolute economic size of investment partners is positively related to the extent of foreign involvement in the host country. Therefore, a positive sign on the GDPSUM variable should be expected. To calculate the sum of investment partners' GDP we use the same data on GDP that was used previously to calculate the GDP similarity index which comes from the PennWorld Table (PWT) 9.0.

In order to control for the effects of transport and other distance related costs such as communication and monitoring we include geographic distance (DISTANCE) between the home country and Poland. The economic theory, however, does not yield clear predictions about the exact impact of distance on the extent of foreign involvement in the host country. On the basis of previous empirical studies we can expect a negative sign of

FDI when the host country is very human capital-scarce. However, the theory cannot exactly predict where the turning point is (Carr et al., 2004). 
the estimated coefficient on the DISTANCE variable. We choose to measure distance in the simplest possible way by calculating a "as the crow flies" distance between European capitals and the capital city of Poland - Warsaw and express it in kilometers. This data is available on line from http://www.indo.com/distance.

Finally, to control for business cycle and policy changes effects such, as joining the EU in 2004, we also include individual time effects and to control for cross-country heterogeneity we include country-pair fixed effects. The inclusion of individual country-pair fixed effects allows also controlling implicitly for other forms of distance stressed by international business economists, such as cultural distance, and other country specific factors that are constant over time such as common historical background.

The definitions of the dependent and explanatory variables and their summary statistics are shown in Table $1 .^{5}$

Table 1. Definitions and summary statistics of dependent and explanatory variables and their expected signs

\begin{tabular}{|c|c|c|c|c|c|}
\hline $\begin{array}{c}\text { Explanatory } \\
\text { variable }\end{array}$ & Definition & Mean & Std. dev. & Min & Max \\
\hline MNE & Number of firms with foreign capital & 764.91 & 1242.63 & 0 & 6303 \\
\hline GDPPCDIFF & $\begin{array}{c}\text { Per capita GDP difference between } \\
\text { parent country and Poland }\end{array}$ & 17870.64 & 7452.43 & 235.21 & 46666.89 \\
\hline HLDIFF & $\begin{array}{c}\text { Human capital per worker differ- } \\
\text { ence }\end{array}$ & 0.2636 & 0.2138 & 0.0009 & 0.8998 \\
\hline KLDIFF & Capital per worker difference & 183962.90 & 72660.18 & 50610.21 & 421443.30 \\
\hline SIMILARITY & Helpman GDP dispersion index & 0.3731 & 0.1032 & 0.0624 & 0.4999 \\
\hline GDPSUM & $\begin{array}{c}\text { Sum of parent country and Poland's } \\
\text { GDPs }\end{array}$ & 1368554 & 933535.60 & 309587.30 & 4694847 \\
\hline DISTANCE & $\begin{array}{c}\text { Geographic distance of each parent } \\
\text { country's capital city from Warsaw }\end{array}$ & 1292.27 & 609.75 & 515 & 2756 \\
\hline
\end{tabular}

Source: own calculations performed in STATA 11.

Our measure of the extent of foreign involvement in Poland's economy is the number of operational entities with foreign capital participation obtained from the Polish Central Statistical Office (CSO). ${ }^{6}$ According to the most recent CSO (2015) data in 2014 there were 26464 operational firms with foreign equity and 18517 of this total $(70 \%)$ reported equity that belonged to investors located in the EU-15 countries. The top three source countries were, respectively, Germany with 6041 firms (22.8\%), the Netherlands with 2575 firms (9.7\%), and the UK with 1384 firms (5.2\%). The majority of multinational enterprises as well as the foreign equity were concentrated in service and manufacturing activities and foreign involvement in the primary sector was negligible.

Our dependent variable assumes non-negative integer values and the distribution of firms is skewed towards a few EU-15 source countries. The preponderance of zeros and small values in the sample, as well as the clearly discrete nature of the dependent variable, suggest

\footnotetext{
${ }^{5}$ The calculated values of the correlations between all the variables used in the empirical study are reported in Table $\mathrm{A} 1$ in the Appendix.

${ }^{6}$ CSO, 2015, The economic activity of firms with foreign capital participation, Zakład Wydawnictw Statystycznych, Warszawa.
} 
that we can improve on traditional estimation techniques, such as OLS for example, with a specification that accounts for these features. Therefore, in order to validate the theoretical predictions of the modified $\mathrm{KC}$ model of multinational enterprise and identify the main reasons for undertaking FDI in Poland by foreign firms from the EU-15 countries, the use of count models in this study seems to be the most suitable choice. The Poisson and negative binomial (NB) models are two most popular count models. In the Poisson model the probability of observing a count of foreign firms from country $i y_{i}$ that operate in Poland is:

where:

$$
\operatorname{Pr}\left(y_{i} \mid x_{i}\right)=\frac{e^{-\lambda_{i}} \lambda^{y_{i}}}{Y_{i} !}
$$

$y_{i}=0,1,2, \ldots, N$;

$\lambda_{i}$ is the expectation of the number of multinational firms from country $i$ operating in Poland, assumed to be log-linearly dependent on the vector of country characteristics $x_{i}$ :

$$
\ln \lambda_{i}=\beta^{\prime} x_{i}
$$

where:

$\beta$ is a parameter vector that needs to be estimated.

The crucial assumption of the Poisson model is the equality of conditional variance and conditional mean. However, count data very often exhibits overdispersion. This problem can be easily avoided by using the NB model which is a generalized version of the simple Poisson model that introduces an individual unobserved effect into the conditional mean:

where:

$$
\ln \lambda_{i}=\beta^{\prime} x_{i}+\varepsilon_{i}
$$

$\varepsilon_{i}$ reflects either a specification error or some cross-sectional heterogeneity with $\exp \left(\varepsilon_{i}\right)$ having a gamma distribution with a unit mean and variance $\alpha$.

The expected value $y_{i}$ in the negative binomial model is exactly the same as in the Poisson model but the variance is bigger than the mean and equals:

$$
\operatorname{var}\left[y_{i} \mid x_{i}\right]=E\left[y_{i} \mid x_{i}\right]\left\{1+\alpha E\left[y_{i} \mid x_{i}\right]\right\}
$$

The negative binomial model approaches the Poisson model as overdispersion approaches zero. When the estimated parameter $\alpha$ is not statistically different from zero, the conditional mean becomes equal the conditional variance and the negative binomial model simplified to the Poisson model. Hence, the Poisson model is nested in the negative binomial model. In order to make the comparison between these two models the standard likelihood ratio test can be used. In this study we estimated both the Poisson and NB models. However, it turned out that in all cases the estimated parameter $\alpha$ was statistically different from zero and the likelihood ratio test always favored the NB model versus the Poisson model. Therefore, in the next section we report only the negative binomial model estimates.

\section{RESULTS AND DISCUSSION}

In this section we report two sets of our estimation results. First, in order to achieve comparability with the earlier studies, in Table 2 we report estimation results obtained for the specification in which we use GDP per capita as a measure of relative factor en- 
dowments. Then, in Table 3 we report estimation results obtained from the specification in which we use the actual human and physical capital per worker data.

Table 2. Estimates of the NB model for the period 1989-2014: GDP per capita data

\begin{tabular}{|c|c|c|c|c|}
\hline Explanatory variable & (1) & (2) & (3) & (4) \\
\hline GDPPCDIFF & $\begin{array}{c}0.000087^{* * *} \\
(12.33)\end{array}$ & $\begin{array}{c}0.000069 * * * \\
(10.65)\end{array}$ & $\begin{array}{c}0.000078^{* * *} \\
(7.84)\end{array}$ & $\begin{array}{c}0.000043^{* * *} \\
(5.20)\end{array}$ \\
\hline SIMILARITY & $\begin{array}{c}3.759283^{* * *} \\
(9.34)\end{array}$ & $\begin{array}{c}3.575377^{* * *} \\
(10.55)\end{array}$ & $\begin{array}{c}-6.201976^{* * *} \\
(4.92)\end{array}$ & $\begin{array}{c}2.853520^{* * *} \\
(2.92)\end{array}$ \\
\hline GDPSUM & $\begin{array}{c}1.10 \mathrm{e}-06 * * * \\
(23.34)\end{array}$ & $\begin{array}{c}1.01 \mathrm{e}-06 * * * \\
(14.65)\end{array}$ & $\begin{array}{c}1.77 \mathrm{e}-06 * * * \\
(19.83)\end{array}$ & $\begin{array}{c}-6.99 \mathrm{e}-07^{* * *} \\
(4.34)\end{array}$ \\
\hline DISTANCE & $\begin{array}{c}-0.000663^{* * *} \\
(13.65)\end{array}$ & $\begin{array}{c}-0.000935^{* * *} \\
(14.65)\end{array}$ & $\begin{array}{c}0.000599 * * * \\
(3.86)\end{array}$ & $\begin{array}{c}-0.002912^{* * *} \\
(11.92)\end{array}$ \\
\hline Constant & $\begin{array}{l}2.261137^{* * *} \\
(6.81)\end{array}$ & $\begin{array}{c}0.483792 \\
(1.58)\end{array}$ & $\begin{array}{c}2.527454^{* * *} \\
(6.11)\end{array}$ & $\begin{array}{c}6.975686 * * * \\
(13.80)\end{array}$ \\
\hline Time-specific effects & NO & YES & NO & YES \\
\hline Country-specific effects & NO & NO & YES & YES \\
\hline Loglikelihood & -2648.633 & -2539.198 & -2551.608 & -2372.102 \\
\hline Pseudo R2 & 0.096 & 0.133 & 0.129 & 0.190 \\
\hline $\begin{array}{l}\text { Alpha } \alpha \\
\text { (z-stat) }\end{array}$ & $\begin{array}{c}0.532090 \\
(14.36)\end{array}$ & $\begin{array}{c}0.320132 \\
(13.89)\end{array}$ & $\begin{array}{c}0.329316 \\
(13.58)\end{array}$ & $\begin{array}{c}0.129663 \\
(12.61)\end{array}$ \\
\hline $\begin{array}{l}\text { LR test } \\
\text { (p-val) }\end{array}$ & $\begin{array}{l}7.7 e+04 \\
(0.000)\end{array}$ & $\begin{array}{l}6.2 e+04 \\
(0.000)\end{array}$ & $\begin{array}{c}4.7 e+04 \\
(0.000)\end{array}$ & $\begin{array}{l}1.1 \mathrm{e}+04 \\
(0.000)\end{array}$ \\
\hline $\begin{array}{l}\text { Chi2 test for time effects } \\
\text { (p-val) }\end{array}$ & - & $\begin{array}{l}361.02 \\
(0.000) \\
\end{array}$ & - & $\begin{array}{l}629.30 \\
(0.000) \\
\end{array}$ \\
\hline $\begin{array}{c}\text { Chi2 test for country ef- } \\
\text { fects } \\
\text { (p-val) }\end{array}$ & - & - & $\begin{array}{l}251.82 \\
(0.000)\end{array}$ & $\begin{array}{l}548.78 \\
(0.000)\end{array}$ \\
\hline
\end{tabular}

Notes: Dependent variable: the number of multinational enterprises; $\mathrm{N}=390$ in all specifications; * significant at the $10 \%$ level of significance, ${ }^{* *}$ significant at the $5 \%$ level of significance, ${ }^{* * *}$ significant at the $1 \%$ level of significance. Source: own estimations performed in STATA 11.

The baseline estimates obtained via the traditional NB approach on the pooled dataset without controlling for individual time and country-pair specific effects are presented in column (1) of Table 3. It turns out that almost all estimated coefficients are statistically significant already at the $1 \%$ level and display expected signs with the exception of differences in human capital per worker. In particular, the positive signs of the estimated parameters on both the measure of differences in capital-labor ratios and on the measure of similarity in terms of market size suggest that both vertical and horizontal reasons are important for multinational activity in Poland. These findings are in line with the estimation results reported in column (1) of Table 2. However, they do not fully support the original knowledge capital model where differences in human capital abundance play a key role in determination of the extent of multinational activity. Nevertheless, they are in line with the results of the modified KC model in which the physical capital is also included as an important factor of production.

In column (2) we control for individual time specific effects by including dummy variables for particular years of our sample. Similar to the estimates reported in column (2) of Table 2, the estimated coefficients on time effects are jointly statistically significant, as indi- 
cated by the high value of chi2 test. Their inclusion improves the accuracy of our baseline estimates, reported in column (1), which is reflected in the higher value of the loglikelihood and pseudoR ${ }^{2}$ suggesting a better fit of the empirical model. However, the inclusion of individual time effects makes the capital-labour ratio statistically not significant. This would suggest that only the horizontal reason for multinational activity in Poland is important.

In column (3) we control for individual country-specific effects by including dummy variables for particular countries in our sample. Similar to the estimates reported in column (3) of Table 2, the estimated coefficients on country-specific effects are jointly statistically significant, as indicated by the value of chi2 test. Their inclusion improves the accuracy of our baseline estimates, reported in column (1), which is reflected in the higher value of the loglikelihood and pseudo $R^{2}$ suggesting a better fit of the empirical model. Compared to the baseline results from column (1), the inclusion of countryspecific effects does not change much statistical significance of the estimated parameters on our explanatory variables with the exception of the human capital differences variable which becomes statistically significant but only at the $10 \%$ level. Our previous conclusions concerning the impact of differences in capital to labor ratios on the extent of foreign involvement in Poland remain unchanged as the estimated parameter on this variable displays the positive sign and is statistically significant already at the $1 \%$ level. In addition, the inclusion of country-specific effects changes the sign of the estimated parameter on the measure of similarity in terms of the market size which now becomes negative and statistically significant only at the $5 \%$ level.

Finally, in column (4) we include both country-specific effects and time-specific effects. These estimation results differ from the baseline results reported in column (1) as now both measures of differences in relative factor endowments become statistically significant already at the $1 \%$ level and display the expected positive signs. The estimated coefficients on similarity in market size also displays the expected positive signs and is statistically significant already at the $1 \%$ level. However, this time the sign of the estimated parameter on the absolute market size now becomes negative and statistically significant at the $1 \%$ level. These estimation results suggest that both differences in relative factor endowments as well as the market access are important for multinational firms based in the EU-15 countries that undertake FDI in Poland. These empirical findings are generally in line with the predictions of the modified knowledge capital model of multinational enterprise and support the significance of both horizontal and vertical reasons for undertaking FDI in Poland by firms from the EU-15 countries. These results are also quite similar to the results of several previous empirical studies for other countries, discussed in the literature review section, that supported both reasons for FDI.

\section{CONCLUSIONS}

The purpose of this paper was to validate empirically the theoretical predictions of the modified knowledge capital model of multinational enterprise that combines horizontal and vertical reasons for FDI using bilateral panel data on EU-15 MNE activity in Poland during the last 26 years. According to this model multinational enterprises arise endogenously in response to country characteristics such as differences in relative factor endowments, relative economic size, as well as trade costs. The assembled empirical evidence pointed to the horizontal as well as vertical motives for undertaking 
foreign direct investment in Poland. In addition, differences in both relative human capital endowments and physical capital to labour ratios were found to be important for determining the extent of MNE activity in Poland. These findings suggest that government should not try to attract only one type of FDI.

The empirical evidence reported in this paper concerns, however, only the case of the old EU-15 countries which is a major limitation of the current study. Therefore, in future studies the robustness of the empirical findings for the old EU-15 countries should be verified on the extended sample of countries that would include also those countries that did not invest much or did not invest in Poland at all to address the problem of zero observations in the dataset. Another important limitation of the current study is the focus only on one type of distance - geographical distance while many recent studies in the international business literature stress the role of other forms of distance such as cultural or psychic distance. These other forms of distance should also be taken into account in future studies of FDI determinants in Poland, in particular when non-European source countries are considered.

\section{REFERENCES}

Ancyparowicz, G. (2009). Bezpośrednie inwestycje zagraniczne w Polsce po akcesji do Unii Europejskiej, Zeszyty Naukowe SGGW, Ekonomika i Organizacja Gospodarki Żywnościowej, 77, 89-103.

Baniak, A., Cukrowski, J., \& Herczyński, J. (2005). On the determinants of foreign direct investment in transition economies, Problems of Economic Transition, 48(2), 6-28.

Benacek, V., Gronicki, M., Holland, D., \& Sass, M. (2000). The determinants and impact of foreign direct investment in Central and Eastern Europe: A comparison of survey and econometric evidence, Transnational Corporations, 9(3), 163-212.

Bergstrand, J.H., \& Egger, P. (2007). A knowledge and physical capital model of international trade flows, foreign direct investment and multinational enterprises, Journal of International Economics, 73(2), 278-308.

Bergstrand, J.H., \& Egger, P. (2013). Shouldn't physical capital also matter for multinational enterprise activity?, Review of International Economics, 21(5), 945-965.

Bevan, A.A., \& Estrin, S. (2004). The determinants of foreign direct investment into European transition economies, Journal of Comparative Economics, 32(4), 775-787.

Braconier, H., Norbäck, P.J., \& Urban, D. (2005). Reconciling the evidence on the knowledge capital model, Review of International Economics, 13(4), 770-786.

Brainard, L.S. (1993a). A simple theory of multinational corporations and trade with a tradeoff between proximity and concentration, NBER Working Paper 4269.

Brainard, L.S. (1993b). An empirical assessment of the factor proportions explanation of multinational sales, NBER Working Paper 4580.

Brainard, L.S. (1997). An empirical assessment of the proximity concentration tradeoff between multinational sales and trade, American Economic Review, 87(4), 520-544.

Brenton, P., Di Mauro, F., \& Lucke, M. (1999). Economic integration and FDI : An empirical analysis of foreign investment in the EU and in Central and Eastern Europe, Empirica, 26(2), 95-121.

Carr, D.L., Markusen, J.R., \& Maskus, K.E. (2001). Estimating the knowledge capital model of the multinational enterprise, American Economic Review, 91(3), 693-708. 
Carr, D.L., Markusen, J.R., \& Maskus, K.E. (2004). Competition for multinational investment in developing countries: Human capital, infrastructure and market size. In R.E. Baldwin \& A.L. Winters (eds.), Challenges to Globalization: Analyzing the Economics, Chicago: University of Chicago Press.

Carstensen, K., \& Toubal, F. (2004). Foreign direct investment in Central and Eastern European countries: A dynamic panel analysis, Journal of Comparative Economics, 32(1), 3-22.

Chen, Y., Horstmann, I.J. \& Markusen, J.R. (2012). Physical capital, knowledge capital, and the choice between FDI and outsourcing, Canadian Journal of Economics, 45(1), 1-15.

Cieślik, A. (1996). FDI in Central Europe's Transition: Early Results, Faculty of Economic Sciences Economic Discussion Paper 28.

Cieślik, A. (2006). Why do multinational firms invest in Poland? Horizontal vs. vertical FDI. In The Influence of the Globalisation Processes on Central and Eastern European Region (pp. 379390). Sopot: Gdańsk University Press.

Cieślik, A. (2013). Horizontally-integrated MNE and plant heterogeneity, Bank i Kredyt, 44(6), 605-622.

Cieślik, A. (2015a). North-North FDI, exporting and the first mover advantage, Bank i Kredyt, 46(2), 109-128.

Cieślik, A. (2015b). Imperfect competition, productivity differences and proximity-concentration trade-offs, Ekonomia, 40, 7-30.

Cieślik, A. (2016). Exports versus FDI in Smith-Motta framework, Equilibrium. Quarterly Journal of Economics and Economic Policy, 11(2), 189-218.

Cieślik, A., \& Ryan, M. (2004). Explaining Japanese direct investment flows into an enlarged Europe: A comparison of gravity and economic potential approaches, Journal of the Japanese and International Economies, 18, 12-37.

Cieślik, A., \& Ryan, M. (2012). Productivity differences and foreign market entry in an oligopolistic industry, Open Economies Review, 23(3), 531-557.

Collie, D.R. (2011). Multilateral trade liberalization, foreign direct investment and the volume of world trade, Economics Letters, 113(1), 47-49.

Davies, R.B. (2008). Hunting high and low for vertical FDI, Review of International Economics, 16(2), 250-267.

Garibaldi, P., Mora, N., Sahay, R., \& Zettelmeyer, J. (2001). What moves capital to transition economies?, IMF Staff Papers, 48, 109-145.

Gorbunova, Y., Infante, D., \& Smirnova, J. (2012). New evidence on FDI determinants: An appraisal over the transition period, Prague Economic Papers, 2, 129-149.

Helpman, E. (1984). A simple theory of trade with multinational corporations, Journal of Political Economy, 92, 451-471.

Helpman, E. (1985). Multinational corporations and trade structure, Review of Economic Studies, 52, 443-458.

Helpman, E. (1987). Imperfect competition and international trade: Evidence from fourteen industrial countries, Journal of the Japanese and International Economies, 1(1), 62-81.

Helpman, E., \& Krugman, P. (1985). Market structure and foreign trade: Increasing returns, imperfect competition and the international economy, MIT Press, Cambridge M.A.

Helpman, E., Melitz, M.J., \& Yeaple, S.R. (2004). Export versus FDI with heterogeneous firms, American Economic Review, 94(1), 300-316.

Horstmann, I., \& Markusen, J.R. (1987). Strategic investments and the development of multinationals, International Economic Review, 28, 109-121.

Jasiniak, M. (2014). Bezpośrednie inwestycje zagraniczne w Polsce w warunkach międzynarodowego kryzysu gospodarczego, Zeszyty Naukowe Uniwersytetu Szczecińskiego, 804, 793-802. 
Kemp, M.C. (1962). Foreign direct investment and the national advantage, Economic Record, 38(81), 56-62.

Krugman, P. (1983). The 'New Theories' of international trade and multinational enterprise. In D.B. Audretsch \& Ch.P. Kindleberger (eds.), The Multinational Corporation in the 1980s (Ch.3.). Cambridge MA: MIT Press.

Lansbury, M., Pain, N., \& Smidkova, K. (1996). Foreign direct investments in Central Europe since 1990: An econometric study, National Institute Economic Review, 156, 104-113.

Liberska, B. (1999). Czynniki przyciągające zagraniczne inwestycje bezpośrednie. Wnioski dla Polski z doświadczeń innych krajów, in: Z. Sadowski (ed.), Kapitał zagraniczny w Polsce. Warunki działania (pp. 35-64). Warszawa: PTE.

Lizińska, W. (2012). Zmiany motywów podejmowania bezpośrednich inwestycji zagranicznych w Polsce, Prace i Materiały Instytutu Handlu Zagranicznego Uniwersytetu Gdańskiego, 31(1), 673-686.

MacDougall, G.D.A. (1960). The benefits and costs of private investment from abroad: A theoretical approach, Oxford Bulletin of Economics and Statistics 22(3), 180-211.

Markowicz, I., \& Miłaszewicz, D. (2007). Analiza determinant bezpośrednich inwestycji zagranicznych w Polsce, Wiadomości Statystyczne, 6, 24-33.

Markusen, J.R. (1984). Multinationals, multi-plant economies and the gains from trade, Journal of International Economics, 16, 205-226.

Markusen, J.R. (2002). Multinational firms and the theory of international trade, MIT Press, Cambridge M.A.

Markusen, J.R. (2013). Multinational firms, In D. Bernhofen, R. Falvey, D. Greenaway, \& U. Kreickemeier (eds.), Palgrave Handbook of International Trade (pp. 236-262). Basingstoke: Palgrave Macmillan.

Markusen, J.R., \& Stähler, F. (2011). Endogenous market structure and foreign market entry, Review of World Economics, 147(2), 195-215.

Markusen, J.R., \& Strand, B. (2009). Adapting the knowledge-capital model of the multinational enterprise to trade and investment in business services, World Economy, 32(1), 6-29.

Markusen, J.R., \& Venables, A.J. (1998). Multinational firms and the new trade theory, Journal of International Economics, 46, 183-203.

Markusen, J.R., \& Venables, A.J. (2000). The theory of endowment, intra-industry and multinational trade, Journal of International Economics, 52, 209-234.

Motta, M. (1992). Multinational firms and the tariff jumping argument, European Economic Review, 36, 1557-1571.

National Bank of Poland, (2015). Foreign direct investment inward position at the end of 2014 broken down by country and economic zone, http://www.nbp.pl/homen.aspx?f=/en /publikacje/ziben/ziben.html

Neary, P.J. (2009). Trade costs and foreign direct Investment. International Review of Economics \& Finance, 18(2), 207-218.

Owczarczuk, M. (2014). Atrakcyjność inwestycyjna Polski z perspektywy instytucjonalnej, Studia Ekonomiczne, 184, 168-180.

Polak, W. (2002). Determinanty napływu zagranicznych inwestycji bezpośrednich do Polski w okresie transformacji, Zeszyty Naukowe Akademii Morskiej w Gdyni, 43, 63-80.

Przybylska, K. (1998). Czynniki determinujące przypływ zagranicznych inwestycji bezpośrednich do Polski, Ekonomista, 2-3, 325-340. 
Przybylska, K. (2001). Determinanty zagranicznych inwestycji bezpośrednich w teorii ekonomicznej: Empiryczna weryfikacja czynników lokalizacji zagranicznych inwestycji bezpośrednich w Czechach, Polsce i na Węgrzech, Zeszyty Naukowe / Akademia Ekonomiczna w Krakowie. Seria Specjalna, Monografie $\mathrm{nr} 144$.

Sinha, U.B. (2010). Strategic licensing, exports, FDI, and host country welfare, Oxford Economic Papers, 62(1), 114-131.

Smith, A. (1987). Strategic investment, multinational corporations and trade policy, European Economic Review, 31, 89-96.

Wach, K., \& Wojciechowski, L. (2016). Determinants of inward FDI into Visegrad countries: Empirical evidence based on panel data for the years 2000-2012, Economics and Business Review, 2(1), 34-52.

Witkowska, J. (1996). Bezpośrednie inwestycje zagraniczne w Europie Środkowowschodniej: próba interpretacji na gruncie teorii bezpośrednich inwestycji zagranicznych i teorii integracji, Wydawnictwo Uniwersytetu Łódzkiego. 


\section{Appendix A1:}

Table A1. Correlations between variables

\begin{tabular}{|l|r|r|r|r|r|r|r|}
\hline \multicolumn{1}{|c|}{ variable } & \multicolumn{1}{c|}{ MNES } & GDPPCDIFF & HLDIFF & \multicolumn{1}{c|}{ KLDIFF } & SIMILARITY & GDPSUM & DISTANCE \\
\hline MNES & 1.000 & 0.1931 & 0.1426 & 0.1079 & -0.1391 & 0.7085 & -0.3974 \\
\hline GDPPCDIFF & 0.1931 & 1.000 & -0.0932 & 0.1124 & -0.4985 & 0.5097 & -0.0903 \\
\hline HLDIFF & 0.1426 & -0.0932 & 1.000 & -0.1152 & -0.0347 & 0.2443 & 0.2223 \\
\hline KLDIFF & 0.1079 & 0.1124 & -0.1152 & 1.000 & -0.5118 & 0.0332 & -0.1235 \\
\hline SIMILARITY & -0.1391 & -0.4985 & -0.0347 & -0.5118 & 1.000 & -0.4680 & 0.1553 \\
\hline GDPSUM & 0.7085 & 0.5097 & 0.2443 & 0.0332 & -0.4680 & 1.000 & -0.2267 \\
\hline DISTANCE & -0.3974 & -0.0903 & 0.2223 & -0.1235 & 0.1553 & -0.2267 & 1.000 \\
\hline
\end{tabular}

Source: own calculations performed in STATA 11.

\section{Author}

\section{Andrzej Cieślik}

Professor in the Area of International Economics in the Faculty of Economic Sciences of the University of Warsaw (Poland). PhD in Economics by the University of Warsaw (Poland).

Correspondence to: Prof. Andrzej Cieślik, PhD, University of Warsaw, Faculty of Economic Sciences, ul. Długa44/50, 00-241 Warsaw, Poland, e-mail: cieslik@wne.uw.edu.pl

\section{Acknowledgements and Financial Disclosure}

The article came into being within the project no. 2015/19/B/HS4/03230 entitled 'Determinants of Foreign Direct Investment in Poland' financed by National Science Centre conducted by Andrzej Cieślik in the years 2016-2018. The Author would like to thank anonymous reviewers and the participants of the XXII scientific conference of the Department of Foreign Trade of the Cracow University of Economics held on November 7, 2016 in Cracow for their helpful comments and suggestions on the earlier draft of this paper.

\section{Copyright and License}

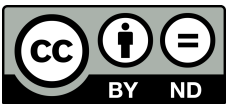

This article is published under the terms of the Creative Commons

Attribution - NoDerivs (CC BY-ND 4.0) License

http://creativecommons.org/licenses/by-nd/4.0/

Published by the Centre for Strategic and International Entrepreneurship - Krakow, Poland 
